\title{
KONSEP PENGEMBANGAN MASTERPLAN BANGSAL SEWOKOPROJO KABUPATEN GUNUNGKIDUL
}

\author{
Dita Ayu Rani Natalia ${ }^{1^{\star}}$, Annisa Nurul Lazmi ${ }^{2}$ \\ ${ }^{1}$ Jurusan Arsitektur, Fakultas Sains dan Teknologi, Universitas Teknologi Yogyakarta, Jalan \\ Glagahsari No. 63 Yogyakarta, Kode Pos 55164 \\ ${ }^{2}$ Jurusan Magister Arsitektur, Fakultas Teknik, Universitas Gadjah Mada, Jl. Grafika No.2, Kode Pos \\ 55284 \\ *ditayurani@uty.ac.id
}

Diterima: 18-09-2020Ｄireview : 20-09-2020 Direvisi : 29-12-2020 Disetujui: 09-01-2021

\begin{abstract}
ABSTRAK. Bangsal Sewokoprojo merupakan salah satu bangunan cagar budaya dan meurupakan asal muasal pusat pemerintahan di Kabupaten Gunungkidul. Kawasan bangsal telah mengalami perubahan dengan penambahan bangunan baru dan pada area pendopo yang merupakan bangunan utama yang menyebabkan hilangnya nilai dan keaslian bangunan. Pemerintah Gunungkidul telah melakukan kajian dan akan mengembalikan fungsi dan bentuk kawasan bangsal Sewokoprojo sesuai dengan aslinya. Pada pengembalian fungsi tersebut terdapat beberapa penyesuaian termasuk pembongkaran bangunan kantor yang baru dan dipindahkan ke kawasan perkantoran terpadu. Tujuan dari pengembangan masterplan Bangsal adalah mengembalikan fungsi dan kawasan Bangsal sebagai bangunan yang menjadi asal mula pusat pemerintahan di kabupaten Gunungkidul serta upaya untuk melestarikan bangunan cagar budaya. Metode yang digunakan dalam penelitian ini adalah kombinasi pendekatan kualitatif untuk menggali dan mendapatkan informasi lebih detail mengenai bangunan dan kuantitatif untuk menindaklanjuti hasil yang dicapai pada pendekatan kualitatif guna membantu dalam pengembangan Bangsal Sewokopraja Kabupaten Gunungkidul. Hasil dari penelitian ini adalah konsep pengembangan kawasan masteplan bangsal yang menggunakan zonasi dan karakteristik bangunan tradisional Jawa sebagai salah satu cara dalam melestarikan nilai budaya dalam pelestarian bangunan cagar budaya di Kabupaten Gunungkidul.
\end{abstract}

Kata kunci: masteplan, bangsal Sewokoprojo, Gunungkidul

ABSTRACT. Bangsal Sewokoprojo (Sewokoprojo Ward) is one of the cultural heritage buildings and is the origin of the central government in the Gunungkidul Regency. The ward area has changed with the addition of new buildings, and at the hall area, the main building, causing loss of value and authenticity of the building. The Gunungkidul Government has conducted a study and will restore the function and shape of the Sewokoprojo ward area to its original state. There were several adjustments during the restoration of the function, including the demolition of the new office building, then being moved to an integrated office area. The Ward masterplan development aimed to restore the function and area of the Ward as the building that became the origin of the central government in The Gunungkidul Regency and an effort to preserve a cultural heritage building. The method used in this research was a combination of the qualitative approach to explore and obtain more detailed information about the building and the quantitative approach to follow up on the results achieved in the qualitative approach to assist the development of Bangsal Sewokoprojo of The Gunungkidul Regency. This research was the development concept of the masterplan ward area that used zoning and the characteristic of a traditional Javanese building to preserve cultural values in protecting the cultural heritage buildings in The Gunungkidul Regency.

Keywords: masteplan, bangsal Sewokoprojo, Gunungkidul

\section{PENDAHULUAN}

Kabupaten Gunungkidul terletak di sebelah selatan Kota Yogyakarta dengan bentang alam berupa pegunungan sewu yang kaya akan daya tarik wisata. Keunikan alam telah banyak menarik minat wisatawan dari dalam negeri maupun mancanegara. Salah satu daya tarik wisata adalah peninggalan situs purbakala pada beberapa geosite dan bangunan cagar budaya. Undang-Undang Nomor 11 Tahun 2010 tentang benda Cagar budaya, disebut benda cagar budaya Benda Cagar Budaya adalah Benda alam dan/ atau benda buatan 
Manusia, baik Bergerak maupun tidak bergerak, berupa kesatuan atau kelompok, atau bagiannya Atau sisa-sisanya yang memiliki hubungannya erat dengan Kebudayaan dan Sejarah Perkembangan manusia. Ketentuan undang- undang tersebut, menunjukkan, bahwa Benda cagar budaya adalah salah satu aspek Kebudayaan yang perlu mendapat perhatian dalam pembangunan.

Keberadaan warisan budaya dan cagar budaya di wilayah Kabupaten Gunungkidul merupakan kekayaan kultural yang mengandung kearifan lokal sebagai dasar untuk pembangunan kepribadian, pembentukan jati diri serta dalam ketahan sosial budaya masyarakat. Warisan budaya merupakan peninggalan yang bersifat bendawi maupun bukan bendawi. Menurut Peraturan Gubernur No. 56 Tahun 2014 bahwa warisan budaya yang bersifat kebendaan adalah benda, bangunan, struktur, situs, kawasan di darat dan atau di aur yang perlu dilestarikan keberadaaanya karena memiliki nilai penting yang telah tercatat di daftar warisan budaya daerah tapi belum belum ditetapkan sebagai cagar budaya. Benda Cagar Budaya atau lebih tegas tinggalan budaya materil, merupakan bukti-bukti fisik dari perjalanan peradaban bangsa, dan diharapkan menjadi alat untuk menelusuri perjalanan sejarah peradaban bangsa, membangun jiwa kebangsaan atau nasionalisme, menjadi penanda bangsa atau jati diri bangsa dan fungsi-fungsi lain dari tinggalan tersebut, seperti sumber ilmu pengetahuan dan kajian kebudayaan secara umum.

Kabupaten Gunungkidul adalah salah satu kabupaten di Daerah Istimewa Yogyakarta yang mempunyai potensi peninggalan budaya yang salah satunya bangunan awal pusat pemerintahan di Kompleks Bangsal Sewokoprojo. Bangsal Sewokoprojo dibangun pada masa pemerintahan Bupati I Gunungkidul yaitu Bupati Pontjodirjo. Semasa memerintah, peninggalan besar yang Pontjodirjo lakukan, adalah memindahkan pusat pemerintahan dari Pati, Ponjong $\mathrm{Ke}$ Wonosari, atas perintah dari Kasultanan Yogyakarta. Perpindahan pusat pemerintahan karena pada waktu ada perubahan wilayah. Kasultanan Ngayogyakarta yang tadinya hanya Hutan Bunder ke timur hingga perbatasan Mangkunegaran (Solo), ada penambahan wilayah, yakni Patuk (Kandar, 2015).
Kawasan perencanaan merupakan bangunan pusat pemerintahan Kabupaten Gunungkidul pada masa bupati pertama yaitu Pontjodirjo dan berada di Kota Wonosari. Pada kawasan ini terdapat beberapa bangunan antara lain Pendopo, Dalem, dapur dan beberapa bangunan lain yang telah mengalami perubahan dari bangunan aslinya. Pada bagian depan kawasan terdapat Pasar Argosari Wonosari dan kompleks parkir kendaraan. Bangsal Sewokoprojo pada saat ini hanya digunakan untuk acara tertentu sedangkan untuk kantor Bupati berada pada kompleks Pemda Kabupaten Gunungkidul yang terletak pada sisi utara Bangsal. Pada kawasan bangsal terdapat bangunan baru yang digunakan sebagai kantor SatPol PP, BPBD dan Dinas Kebudayaan Kabupaten Gunungkidul.

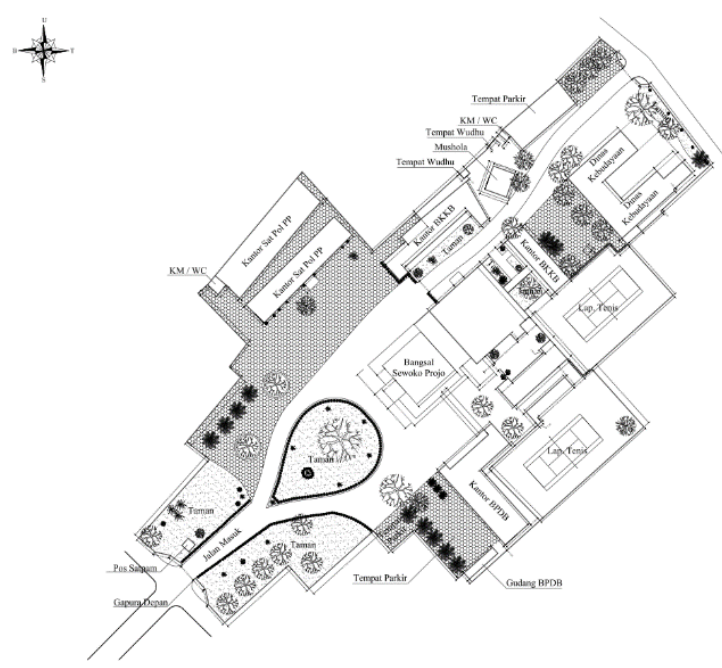

Gambar 1. Kawasan Sewokoprojo Gunungkidul (Sumber: Dokumentasi Pribadi, 2018)

Kawasan bangsal telah mengalami perubahan dan pada tahun 2018, kemudian pemerintah Kabupaten melakukan kajian untuk mengembalikan fungsi dan kawasan seperti semula. Pada pengembalian fungsi tersebut terdapat beberapa penyesuaian termasuk pembongkaran bangunan kantor yang baru dan dipindahkan ke kawasan perkantoran terpadu. Tujuan dari pengembangan masterplan Bangsal adalah mengidentifikasi dan mendiskripsikan pengembangan masterplan dalam upaya dalam melakukan pelestarian bangunan cagar budaya serta memberikan penghargaan terhadap pusaka budaya.

\section{Rumah Jawa}

Dalam susunan bangunan Jawa terdapat konsepsi simetri yang menunjukan 
keselarasan antara hubungan antara manusia dengan alam, manusian dengan manusia, dan manusia dengan Tuhan (Budiwiyanto, 2010). Rumah Jawa menjadi sebuah cerminan dari sikap, pemikiran dan wawasan dalam kapasitas ekonomi, sosial dan kultural masyarakat (Moniaga \& Gunawan, 2019). Rumah tradisi Jawa memiliki bentuk yang beraneka ragam dengan pembagian ruang yang khas, yang terdiri atas pendhapa, pringgitan, dan dalem. Terjadi penerapan prinsip hierarki dalam pola penataan ruang tersebut. Setiap ruangan memiliki perbedaan nilai, ruang pada bagian depan bersifat umum atau publik, sedangkan pada bagian belakang bersifat khusus atau privat. Uniknya, setiap ruangan dari bagian teras, pendhapa sampai bagian belakang atau pawon dan pekiwan tidak hanya memiliki fungsi tetapi juga sarat dengan unsur filosofi hidup pada etnis masyarakat Jawa (Widayat, 2004). Perkembangan sejarah bangunan joglo tidak terlepas dari bangunan purba yang disebut punden berundak, yaitu sebuah bangunan suci (Indrani \& Prasodjo, 2005). Pada bangunan rumah Jawa yang dgunakan oleh masyarajat memakai sumbu kosmis Utara-Selatan, sedangkan sumbu kosmis Barat-Timur digunakan untuk bangunan bangsawan dan Kraton (Cahyani et al., 2019).

Rumah tradisi Jawa memiliki bentuk yang beraneka ragam dengan pembagian ruang yang khas, yang terdiri atas pendhapa, pringgitan, dan dalem. Terjadi penerapan prinsip hierarki dalam pola penataan ruang tersebut. Setiap ruangan memiliki perbedaan nilai, ruang pada bagian depan bersifat umum atau publik, sedangkan pada bagian belakang bersifat khusus atau privat. Uniknya, setiap ruangan dari bagian teras, pendhapa sampai bagian belakang atau pawon dan pekiwan tidak hanya memiliki fungsi tetapi juga sarat dengan unsur filosofi hidup pada etnis masyarakat Jawa (Widayat, 2004). Kehidupan bagi masyarakat Jawa adalah sesuatu yang dicari bukanlah sesuatu yang dihindari atau belakangi. Bangunan rumah sendiri sesungguhnya merupakan sebuah tiruan dari gunung. Dengan demikian, antara gunung dan samudera sebenarnya merupakan sebuah gambaran dari dunia atau kosmos yang saling berhadapan dan bahkan keberadaan keduanya saling disakralkan atau disucikan.

Bentuk dasar rumah Jawa berbentuk bujur sangkar atau empat persegi panjang dan memiliki kesakralan yang lebih ke area belakang bangunan dalem (UNESCO, 2007). Pada rumah jawa, penataan interior pada bangunan dibagi menjadi beberapa kelompok sesuai dengan fungsinya yang terdiri dari pendapa, pringgitan, dalem ageng, senthong tengah, senthing kiwa, senthong tengen dan gandri (Budiwiyanto, 2010).

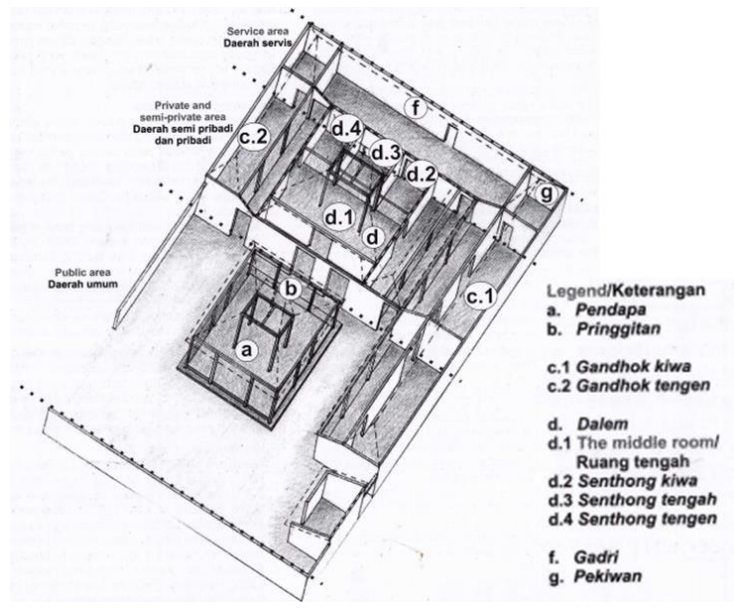

Gambar 2. Pembagian Ruang di Rumah Tradisional (sumber: Jogja Heritage Society, 2007 dalam Tisnawati \& Natalia, 2017)

\section{METODE PENELITIAN}

Metode penelitian menggunakan pendekatan kualitatif dan kuantitatif dengan menggali data untuk mendapatkan informasi yang lebih detail mengenai bangunan Bangsal Sewokopraja. Pendekatan kuatitatif yang digunakan kemudian digunakan ditindaklanjutin dengan pendekatan kualitatif dalam pengembangan Bangsal Sewokopraja Kabupaten Gunungkidul. Metode analisa dilakukan dengan menggunakan metode analisa deskriptif induktif deduktif. Analisa dilakukan dengan dengan mengolah data dari hasil matriks dan variabel yang telah ditentukan yaitu bentuk atap, warna, dimensi bangunan, dan fungsi. Dari data tersebut kemudian dianalisa dalam pengembangan konsep hirarki Jawa dalam desain masterplan.

Kegiatan ini bersifat eksploratif, dengan pencarian dan pengamatan. Cara eksploratif memungkinkan proses pengumpulan data yang memanfaatkan sumber informasi secara luas, tidak terbatas pada ahli yang sudah berpengalaman dalam bidangnya ataupun pelaku pembangunan yang terkait langsung, namun juga dari berbagai literatur. Observasi yang dilakukan dengan cara pengamatan pada fisik bangunan, dokumentasi dan pengukuran antar bangunan. Analisis dilakukan berdasarkan data yang terkumpul kemudian dilakukan pengolahan data baik data dokumentasi, wawancara, hasil pengukuran. 
Dari data tersebut kemudian membuat rekomendasi dalam pengembangan masterplan bangsal Sewokoprojo.

\section{HASIL DAN PEMBAHASAN}

Bangsal Sewokoprojo merupakan bangunan yang memiliki historis dalam perkembangan wilayah Gunungkidul dan perlu dilestarikan dan dipertahankan keasliannya. Pada kondisi eksisting, pada beberapa bangunan telah mengalami perubahan sebagian maupun total. Kurangnya dokumentasi dan data tentang Bangsal Sewokoprojo memberikan kendala dalam proses pelestarian untuk mengembalikan ke bangunan awal. Bangunan pendopo yang masih asli dipertahankan dengan adanya sedikit perubahan dan penambahan pada bagian sisi kanan dan kiri pendopo telah mengalami perubahan bentuk. Kondisi eksisting kawasan Bangsal Sewokoprojo dapat dilihat pada gambar 3.

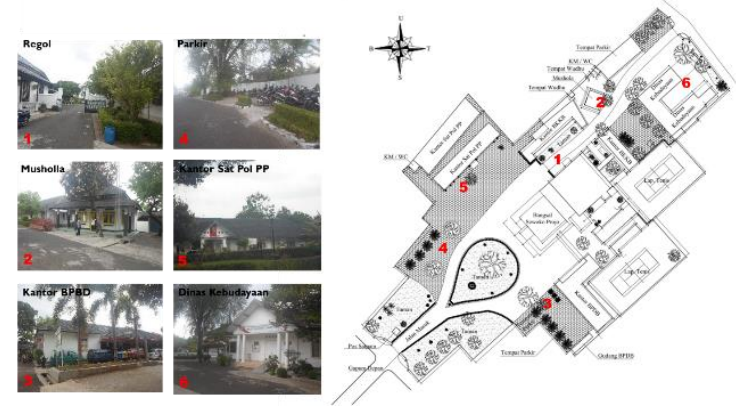

Gambar 3. Kondisi Eksisting (Sumber: Dokumentasi Pribadi, 2018)

Pada kawasan eksisting terdapat penambahan beberapa bangunan baru yang digunakan sebagai kantor dinas, yaitu Kantor Satpol PP, Kantor BPBD, dan Kantor Dinas Kebudayaan. Sedangkan kantor Santel yang terletak di sebelah sisi utara pendopo merupakan bangunan eksisting. Pada bagian kanan pendopo terdapat bangunan dengan bentuk baru yang dahulu merupakan gandhok yang mempunyai fungsi sebagai tempat istirahat. Bangunan yang asli telah mengalami perubahan total dan digantikan dengan tampilan yang lebih baru dan modern. Sedangkan pada gandhok kiwo atau sebelah kiri pendopo masih mempunyai bentuk yang asli dengan adanya perubahan pada elemen bangunan seperti pintu, jendela dan lain-lain.
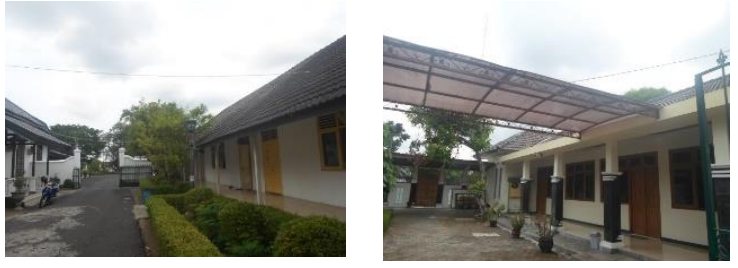

Gambar 4. Kondisi Eksisting Gandhok (Sumber: Dokumentasi Pribadi, 2018

Pada bangunan dapur yang terletak di belakang pendopo tidak mengalami perubahan, hanya beberapa bagian mengalami penambahan selasar dan tritisan. Pada bangunan utama pendopo, beberapa elemen bangunan mengalami perubahan pada tampilan dan adanya penambangan elemen lain, seperti penambahan gebyok pada bagian depan dalem dan penambahan teras di sekeliling pendopo. Pada area itu juga terdapat penambahan area untuk tempat gamelan yang pada awalnya terdapat di dalam pendopo. Pendopo Bangsal Sewokoprojo merupakan salah satu bangunan yang mempunyai sejarah dalam pusat pemerintahan di Kabupaten Gunungkidul. Bangunan tersebut telah mengalami beberapa kali renovasi dan terdapat beberapa penambahan ruang yang disesuaikan dengan kebutuhan untuk kegiatan. Pada kondisi eksisting terdapat beberapa kerusakan yang terjadi pada bangunan sehingga perlu adanya perbaikan karena faktor usia bangunan.

Konsep zonasi penataan kawasan bangsal Sewokoprojo Kabupaten Gunungkidul didasarkan pada karakteristik bangunan tradisional Jawa. Hal tersebut didasarkan pada prinsip revitalisasi pelestarian cagar budaya yang mencerminan komposisi ruang bangunan yang khas selain sangat dipengaruhi oles mitologi proses manifestasi dan kosmologi Jawa. Penataan zonasi masterplan Bangsal Sewokoprojo dapat dilihat pada gambar 5 . 


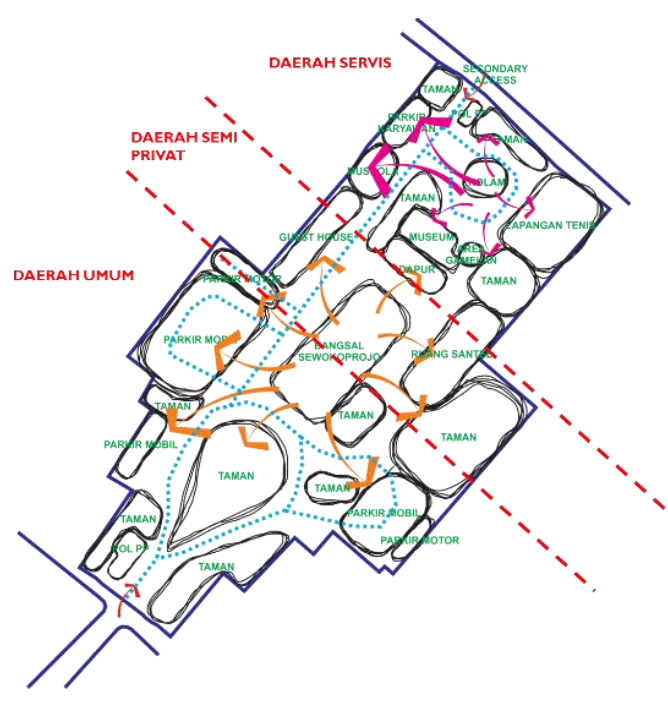

Gambar 5. Konsep Zonasi Kawasan Bangsal Sewokopraja

Pada pengembangan bangsal Sewokoprojo dalam mengembalikan karakteristik bangunan tradisional Jawa maka perlu adanya proses pembongkaran pada beberapa bangunan baru dan mengembalikan seperti keadaan semula. Kawasan Bangsal Sewokoprojo dibagi menjadi 3 zona yaitu pada bagian daerah semi privat dalam tatanan rumah jawa merupakan tempat ndalem, senthong dan gandhok yang merupakan tempat tinggal utama. Pada zonasi ini difungsikan sebagai area guest house dan ruang Informasi. Sedangkan pada bagian dalam pendopo terdapat area yang digunakan untuk tempat kerja Bupati dan Wakil Bupati. Pada bagian belakang yang merupakan daerah servis digunakan sebagai area dapur, parkir karyawan, taman, plaza informasi dan lapangan tenis.

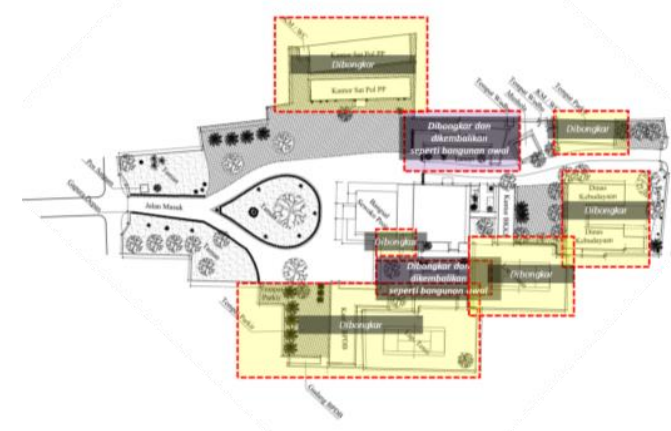

Gambar 6. Rencana Pembongkaran Bangunan

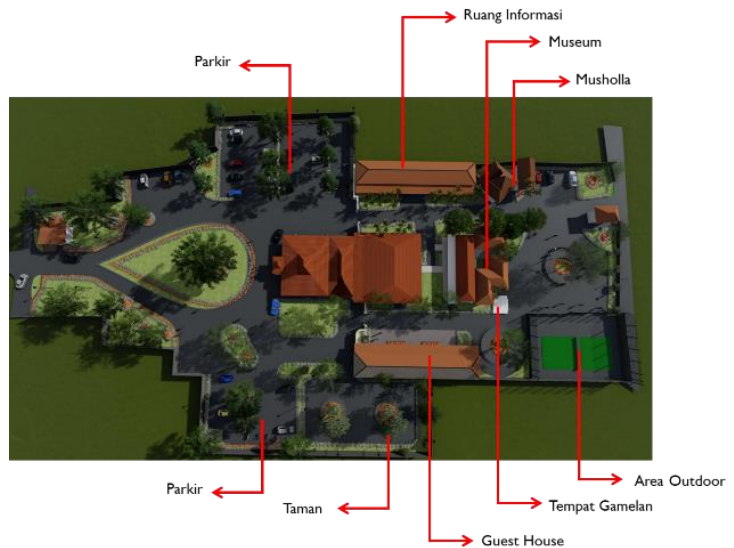

Gambar 7. Perencanan Pengembangan Kawasan Bangsal Sewojoprojo

Penjabaran pengembang zonasi kawasan bangsal sebagai berikut:

\section{Zonasi Publik}

Pada zonasi ini merupakan area umum yang berfungsi sebagai area penerima tamu dan tempat parkir kendaraan bagi pengunjung Bangsal Sewokoprojo. Kondisi eksisting pada zonasi publik terdapat bangunan kantor Satpol PP dan kantor BPBD Kabupaten Gunungkidul. Pada pengembangan masterplan Bangsal Sewokoprojo bangunan di depan regol dibongkar dan digunakan untuk fasilitas parkir dan taman. Penataan hardscape pada area ini menggunakan material aspal dan softscape menggunakan pohon gayam, sawo kecik, dan pohon asem.

\section{Zonasi Semi Privat}

Pada zonasi ini merupakan area semi privat yang berfungsi sebagai area penginapan, kantor informasi, dalem pendopo dan dapur. Pada zonasi rumah jawa, area ini terdapat ruang gandhok, pringgitan (ruang tamu), senthong (tempat istirahat), dalem dan gadri. Pada zonasi di bangsal Sewokoprojo, area tersebut dikembalikan seperti karakteristik rumah Jawa dengan adanya beberapa bagian ruang. Pada kondisi eksisiting bagian pendopo masih mempunyai susunan yang sama tetapi pada bagian pringgitan terdapat ukiran gebyok yang direkomendasikan untuk dibongkar karena merupakan tambahan pada saat renovasi yang dilakukan beberapa tahun yang lalu. Pada area dalem masih digunakan sebagai area tamu untuk menerima tamu yang hadir di Kabupaten Gunungkidul. Ruang senthong pada area pendopo pada jaman dulu digunakan sebagai kantor bupati dan wakil bupati yang sekarang berubah fungsi sebagai ruang istirahat bagi tamu. Pada area gandhok, yang terletak di sebelah kanan dan kiri pendopo telah mengalami perubahan baik 
fungsi maupun bentuk bangunannya. Pada area gandhok kiwo bangunan asli telah mengalami perubahan total yang sekarang digunakan sebagai tempat tinggal dan istirahat bagi Bupati. Sedangkan gandhok tengen pada kondisi eksisiting digunakan sebagai Kantor BKKB.

Rekomendasi dalam perencanaan masterplan bangsal Sewokorojo, ruang istirahat yang terletak di sisi sebelah kanan dan kiri dalem dikembalikan seperti fungsi semula yaitu ruang kerja untuk bupati dan wakil bupati. Sedangkan pada bangunan gandhok yang telah mengalami perubahan bangunan dikembalikan seperti bangunan semula dengan adanya perubahan fungsi pada bangunan.

Kantor BKKB yang terletak di sebelah utara pada perencanaan direkomendasikan untuk berubah fungsi sebagai Ruang Informasi. Sedangkan bangunan yang berada di sisi selatan dikembalikan seperti bangunan semula dengan fungsi sebagai Guest House untuk tempat istirahat bagi tamu yang datang di Kabupaten Gunungkidul. Perubahan dan pengembalian kondisi bangunan seperti awal merupakan bagian dari revitalisasi kawasan Bangsal Sewokoprojo.

Pada kondisi eksisting terdapat lapangan tenis yang berada di sebelah selatan bangunan pendopo. Area tersebut pada perencanaan berubah fungsi sebagai area taman dengan material penutup berupa grass block. Pada bagian pendopo, bangunan tidak mengalami perubahan tetapi mengembalikan bentuk dan tampilan seperti bangunan awal dengan penggunaan warna hijau gading. Pada bagian depan pendopo bagian atap dikembalikan seperti tampilan awal dengan adanya kuncung pada bagian atapnya.

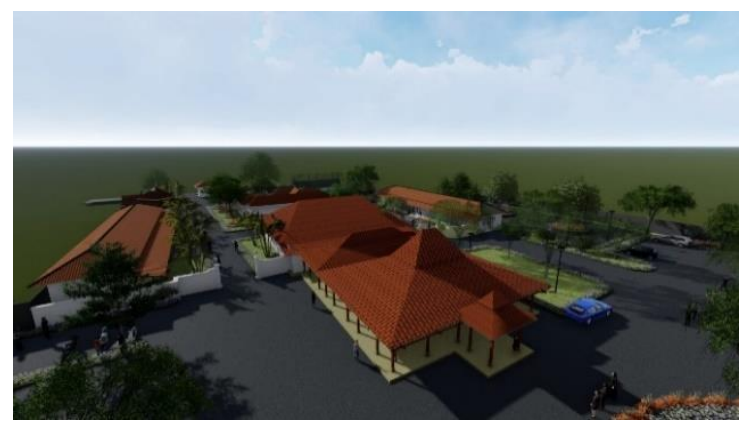

Gambar 8. Pendopo Bangsal Sewokoprojo

Kondisi eksisiting pada bangunan pendopo pada sisi selatan terdapat bangunan baru yang digunakan sebagai tempat gamelan yang merupakan ruang tambahan. Pada perencanaan dan pengembangan, ruang tersebut dibongkar dan teras pada bagian pendopo dikembalikan seperti semula. Sedangkan ruang gamelan yang awalnya berada di Pendopo dipindahkan ke zonasi servis yang berada dbelakang pendopo. Area ruang gamelan kemudian dirubah fungsinya sebagai area taman. Pengembalian fungsi dan bentuk bangunan Pendopo merupakan bagian dari pelestarian dan mempertahankan keaslian pendopo.

Pembangunan dan pengembangan bangunan baru di kawasan kompleks Bangsal Sewokoprojo menggunakan material dan tampilan seperti pada bangunan aslinya. Hal ini berkaitan dengan proses revitalisasi bangunan yang harus memperhatikan keaslian dan nilai budaya. Revitalisasi adalah kegiatan Pengembangan yang ditujukan untuk menumbuhkan kembali nilai-nilai penting Warisan Budaya dan Cagar Budaya dengan penyesuaian fungsi ruang baru yang tidak bertentangan dengan prinsip Pelestarian dan nilai budaya masyarakat. Pembangunan guest house dan Ruang Informasi menggunakan material seperti bangunan asli dengan rangka atap berupa kayu dan beberapa bagian elemen bangunan dikembalikan dengan penggunaan material kayu seperti yang dapat dilihat pada gambar 9 .

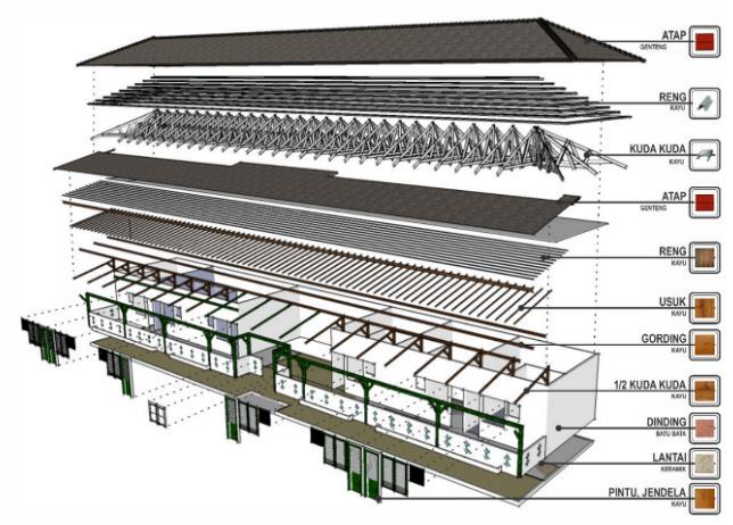

Gambar 9. Material Bangunan

\section{Zonasi Servis}

Pada zonasi terdapat bangunan musholla, parkir karyawan, bangunan mini museum, lapangan tenis dan ruang gamelan. Kondisi eksisting pada area ini terdapat bangunan musholla, parkir, lapangan tenis, dan Kantor Dinas Kebudayaan. Bangunan eksisitng yang terdapat di zona servis dibongkar digantikan dengan fungsi yang berbeda dan tampilan yang sesuai dengan kondisi di lingkungan pendopo. Area yang dibongkar pada zona 
servis dapat dilihat pada gambar 6 di bawah ini.

Bangunan kantor Dinas Kebudayaan dibongkar dan dijadikan area untuk taman, mini museum dan area gamelan. Sedangkan bangunan musholla dan parkir mobil dibongkar dan dibangun musholla baru dengan tampilan bangunan yang memberikan nuansa tradisional agar dapat menyatu dengan bangunan lain di area Bangsal. Bangunan parkir kendaraan dibongkar dan digantikan fungsi dengan area parkir karyawan dengan konsep terbuka.

Konsep bangunan di zona servis pada tampilan menyesuaikan dengan bangunan di sekitar area bangsal yang menggunakan material kayu dengan bentuk atap berupa limasan. Pada pengembangan zona servis, di sisi sebelah selatan terdapat ruang gamelan yang pada awalnya berada di area pendopo. Penempatan ruang gamelan di area servis untuk pertunjukan pada saat adanya tamu atau acara di bangsal karena berdekatan dengan area taman yang dapat digunakan untuk berbagai macam kegiatan kesenian atapun untuk area penyambutan tamu.

Pada pengembangan kawasan di kompleks Bangsal Sewokoprojo, bangunan yang dikembangkan ketinggian bangunan tidak boleh melebihi ketinggian atap Pendopo. Hal ini berkaitan dengan adanya kearifan budaya lokal setempat dan menjaga adanya keselarasan dalam kawasan pendopo. Warna pada bangunan menggunakan warna hijau gading dan kuning yang melambangakn keluhuran atau ketuhanan atau ketentraman, sedangkan warna putih melambangkan kesucian atau kebersihan.

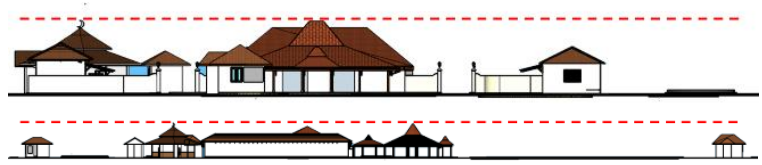

Gambar 10. Potongan Kawasan

Penataan lansekap kawasan menggunakan tanaman yang mempunyai nilai dan filosofi Jawa antara lain pohon sawo kecik, gayam, kepel, asem, kantril dan pule. Penggunaan tersebut didasarkan pada filosofi tanaman sawo kecik yang memiliki makna selalu dalam kebaikan, pohon kepen yang memiliki makan bersatunya niat dengan kerja, pohon asem mempunyi makna ketrentraman hati dan pohon gayam memiliki makna teduh atau tentrem. Penggunaan pohon tersebut mempunyai arti bahwa kawasan Bangsal
Sewokoprojo merupakan tempat yang memberikan ketetraman dan kebaikan dalam bekerja serta sepenuh hati dalam memberikan yang terbaik untuk pengembangan Kabupaten Gunungkidul. Penataan landscape dapat dilihat pada gambar 11 .

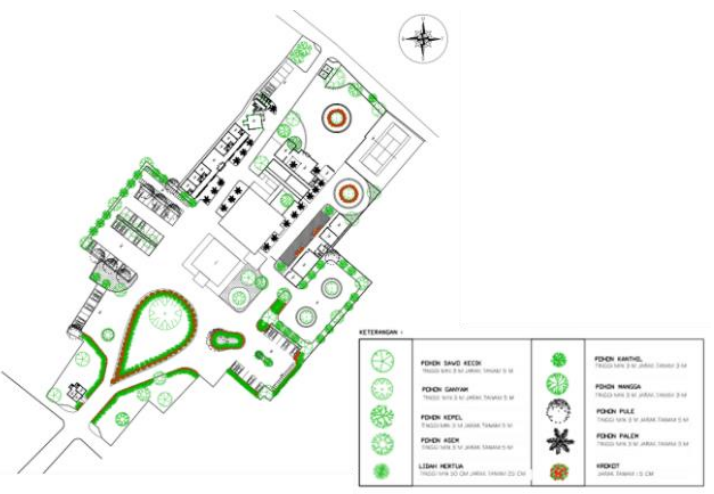

Gambar 11. Softscape Kawasan Bangsal Sewokopraja

Visualisasi pengembangan kawasan Bangsal Sewokoprojo dapat dilihat pada gambar berikut ini.
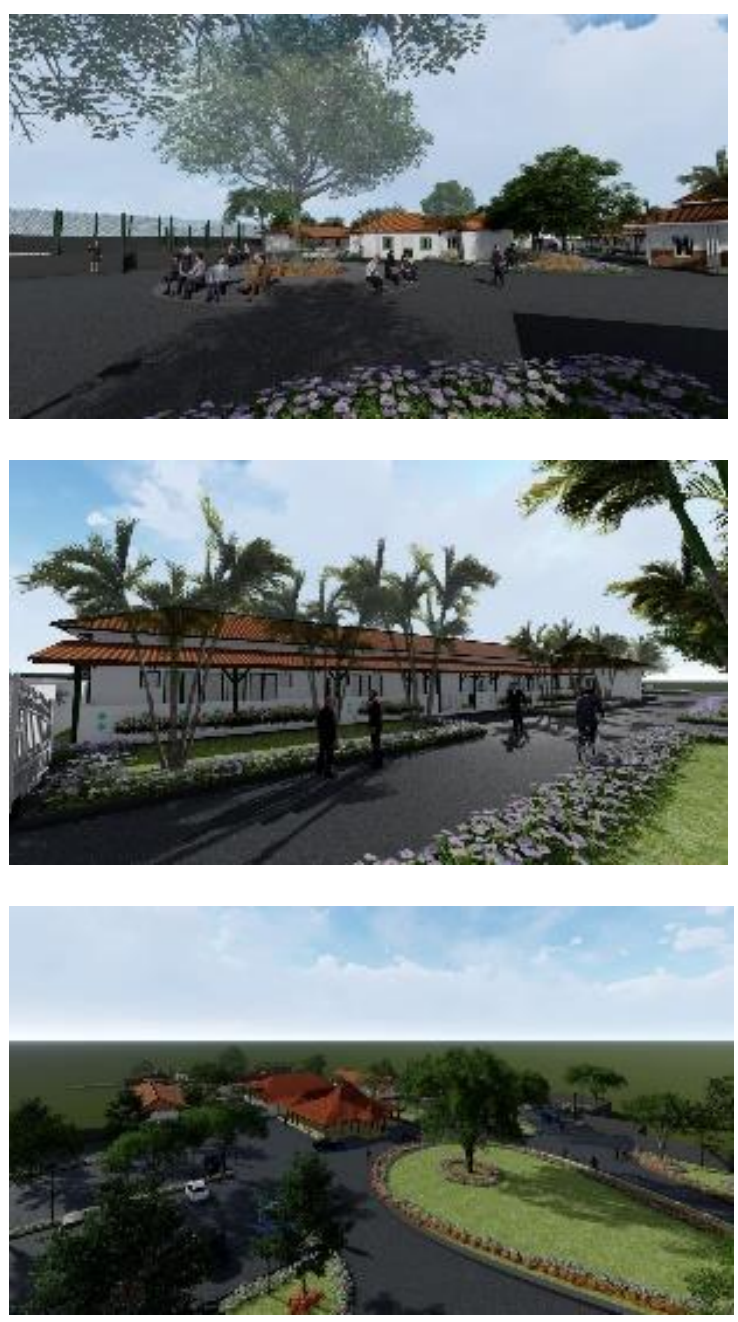


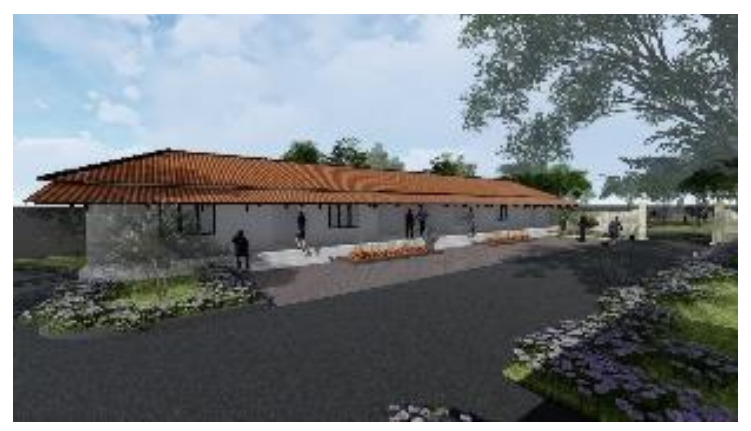

Gambar 12. Visualisasi Pengembangan Masterplan Kawasan Bangsal Sewokopraja
Baru, 1(2).

Tisnawati, E., \& Natalia, D. A. R. (2017) Tipologi Masjid Kagungan Dalem di Imogiri, Bantul. Seminar Ikatan Peneliti Lingkungan Binaan Indonesia (IPLBI), 75-82.

https://doi.org/https://doi.org/10.32315/se m.1.a075

UNESCO. (2007). Kawasan Pusaka Kotagede, Yogyakarta. Indonesia: UNESCO - Jogja Heritage Society.

Widayat, R. (2004). Krobongan Ruang Sakral Rumah Tradisi Jawa. Dimensi Interior, 2(1).

\section{KESIMPULAN}

Kawasan Bangsal Sewokoprojo yang merupakan asal mula pemerintahan di Kabupaten Gunungkidul telah mengalami perubahan baik penambangan bangunan di kawasan maupun penambahan pada bangunan utama. Oleh karena itu maka perlu adanya pengembangan masterplan kawasan Bangsal Sewokoprojo untuk mengidentifikasi dan mendiskripsikan pengembangan dalam upaya dalam melakukan pelestarian bangunan cagar budaya serta memberikan penghargaan terhadap pusaka budaya. Konsep pengembangan masteplan didasarkan pada karakteristik bangunan tradisional Jawa dengan adanya pembangian zona publik, semi publik dan servis dengan melakukan pembongkaran pada bangunan baru di dalam kawasan. Pengembalian tata nilai tersebut diharapkan dapat melestarikan nilai budaya bangunan dan kawasan sebagai salah satu cara dalam pelestarian bangunan cagar budaya di Kabupaten Gunungkidul.

\section{DAFTAR PUSTAKA}

Budiwiyanto, J. (2010). Makna Penataan Interior Rumah Tradisional Jawa. Jurnal Pendhapa, 1(1).

Cahyani, R. ... Antariksa. (2019). Pengaruh Arsitektur Tradisional Jawa dalam Hunian Kolonial di Kampung Bubutan Surabaya. Ruas, 13(1).

Indrani, H. C., \& Prasodjo, M. E. (2005). Tipologi, Organisasi Ruang dan Elemen Interior Rumah Abu Han di Surabaya. Dimensi Interior, 3(1).

Kandar. (2015). Melacak Kisah Bupati Pertama Gunungkidul.

Moniaga, C., \& Gunawan, A. (2019). Rumah Joglo Sebagai Identitas Visual Konsep Bangunan Kuliner Kontemporer. Jurnal Desain Komunikasi Visual Dan Media 